\title{
DISAIN DAN KINERJA SISTEM AIR LAUT YANG DIREFRIGERASI (ALREF) UNTUK PENAMPUNG IKAN PADA KAPAL NELAYAN 10-15 GT
}

\section{Design and Performance of Refrigerated Sea Water (RSW) for Fish Hold on 10-15 GT Fishing Vessels}

\author{
Tri Nugroho Widianto* dan Ahmat Fauzi \\ Loka Riset Mekanisasi Pengolahan Hasil Perikanan, Jl. Imogiri Barat KM 11.5 Jetis, \\ Bantul, DI Yogyakarta, Indonesia \\ *Korespondensi Penulis: trinugrohowidianto@yahoo.com
}

Diterima: 2 April 2018; Direvisi: 25 Juli 2018; Disetujui: 5 November 2018

\begin{abstract}
ABSTRAK
Sistem ALREF (air laut yang direfrigerasi) untuk penyimpanan ikan pada kapal 10-15 GT telah didisain dan diuji. Penelitian ini dilakukan melalui tahapan: penentuan kriteria disain, pembuatan konsep dan analisis disain, konstruksi dan pengujian. Kriteria disain ditentukan berdasarkan referensi kapal 10-15 GT di Pelabuhan Perikanan Pantai Sadeng Gunung Kidul, Yogyakarta. Bak penyimpan ikan dilengkapi pendingin sistem kompresi uap yang terdiri dari komponen utama berupa evaporator, kondensor, kompresor, palka, refrigerant dan katup ekspansi. Palka terbuat dari fiberglass dengan volume palka sekitar 2,03 $\mathrm{m}^{3}$. Palka menggunakan insulator stirofoam high density (densitas sekitar $34 \mathrm{~kg} / \mathrm{m}^{3}$ ). Evaporator terbuat dari pipa tembaga dengan panjang $84 \mathrm{~m}$, diameter $5 / 8$ inchi dan tebal pipa $1,6 \mathrm{~mm}$. Kondensor yang digunakan adalah Alfalaval McDEW 25 menggunakan sistem shell and tube, sedangkan kompresor yang digunakan adalah Blitzer Tipe LH IVY dengan refrigerant R-22. Hasil uji kinerja dengan beban air laut menunjukkan bahwa suhu air laut mencapai kisaran $-0,8$ sampai $-0,4{ }^{\circ} \mathrm{C}$ selama 8,5 jam. Kebutuhan daya listrik sistem pendingin sebesar $2 \mathrm{~kW}$. Uji kinerja dengan beban ikan selama 5 hari menunjukkan bahwa suhu ikan turun dari $27,8{ }^{\circ} \mathrm{C}$ menjadi berkisar $-0,1$ sampai $-1^{\circ} \mathrm{C}$ setelah 12 jam dan dapat dipertahankan selama pengujian.
\end{abstract}

KATA KUNCl: ALREF, kapal nelayan, ikan, penyimpanan ikan

\begin{abstract}
Refrigerated sea water (RSW) system for fish on 10-15 GT fishing vessels had been designed and studied. This study was carried out through defining the design criteria, defining the concept and analyzing the design, manufacturing and testing the performance. Design criteria was determined using references of 10-15 GT fishing vessel used in Sadeng Port of Gunung Kidul, Yogyakarta. The RSW used vapor compression refrigeration system that consists of evaporator, condenser, compressor, fish storage tank, refrigerant and expansion valve. Fish storage tank was made of fiberglass with a volume of about $2.03 \mathrm{~m}^{3}$ using a high density styrofoam insulator (density of $34 \mathrm{~kg} / \mathrm{m}^{3}$ ). Evaporator used copper pipe with length of $84 \mathrm{~m}$, pipe diameter of $5 / 8$ inch and pipe thickness of $1,6 \mathrm{~mm}$. Condenser used was Alfalaval McDEW 25 with shell and tube system, while the compressor used was Blitzer Type LH IVY with refrigerant $R-22$. The performance test of the RSW loaded with sea water showed that the temperature of sea water reached in the range of -0.8 to $-0.4{ }^{\circ} \mathrm{C}$ for 8.5 hours. Electrical power consumption of cooling units was $2 \mathrm{~kW}$. The performance test of the RSW loaded with fish showed that fish temperature dropped from $27.8^{\circ} \mathrm{C}$ to the range of $-0,1$ to $-1{ }^{\circ} \mathrm{C}$ after 12 hours and could be maintained during testing.
\end{abstract}

KEYWORDS: refrigerated sea water, fishing vessel, fish, fish storage

\section{PENDAHULUAN}

Sebagian besar kapal penangkap ikan ukuran kecil (sampai 15 GT) yang terdapat di Pelabuhan Perikanan Pantai (PPP) Sadeng, Yogyakarta dan Pelabuhan Perikanan Samudera (PPS) Cilacap di Jawa Tengah menggunakan es sebagai media pendingin.
Penggunaan es sebagai media pendingin mampu mempertahankan mutu ikan, namun beberapa ikan yang terletak pada bagian bawah palka mengalami kerusakan fisik. Hal ini disebabkan adanya gesekan es dengan permukaan ikan serta adanya gaya tekan es pada ikan selama penyimpanan di dalam palka (Widianto, Fauzi \& Hakim, 2016). Selain itu, 
ketersediaan es berkualitas baik di beberapa TPI masih terbatas serta harganya relatif mahal. Penggunaan es pada kapal kecil juga dapat menambah berat kapal sehingga akan meningkatkan konsumsi bahan bakar. Tuna loin yang diolah di atas kapal dan didaratkan di Ambon mempunyai rata-rata suhu pusat dengan kisaran $10,56-16,53^{\circ} \mathrm{C}$ jauh di atas persyaratan suhu $4,4{ }^{\circ} \mathrm{C}$ untuk tuna sashimi (BSN, 2006). Es yang digunakan juga masih mengandung jumlah bakteri yang cukup tinggi yaitu $10^{6}$ koloni/g, jauh melebihi persyaratan jumlah bakteri pada es balok untuk penanganan ikan yaitu $10^{2} \mathrm{koloni} / \mathrm{g}$ (Suryaningrum, Ikasari \& Octaviani, 2017).

Salah satu alternatif upaya yang dapat digunakan untuk mengatasi masalah tersebut adalah penerapan sistem refrigerasi di atas kapal untuk memperpanjang daya simpan ikan hasil tangkapan nelayan. Penerapan refrigerasi selain untuk mempertahankan mutu ikan juga dapat mengurangi kerusakan fisik ikan akibat gesekan permukaan ikan dengan es serta tekanan es pada ikan yang disimpan pada bagian bawah palka. Selain itu juga dapat mengurangi kontaminasi bakteri yang berasal dari es dan sesuai diaplikasikan pada daerah yang terkendala dengan ketersediaan es. Sistem refrigerasi untuk penyimpanan ikan umumnya dilakukan dengan chilling (pendinginan pada suhu $0{ }^{\circ} \mathrm{C}$ ) dan freezing (pembekuan pada suhu di bawah $-20^{\circ} \mathrm{C}$ ). Pembekuan digunakan pada penyimpanan ikan dalam jangka waktu yang lama dan memerlukan sistem refrigerasi dengan biaya dan energi pendinginan yang cukup besar sehingga untuk aplikasi pada kapal kecil dengan jangka waktu penangkapan sekitar 5-7 hari dinilai kurang efektif. Selain itu, pembekuan yang baik umumnya menggunakan sistem pembekuan cepat agar butiran es yang terbentuk di dalam tubuh ikan berukuran kecil dan halus sehingga tidak mengakibatkan kerusakan pada tekstur ikan akibat terbentuknya kristal es yang besar dan kasar. Pembekuan cepat dapat dilakukan menggunakan metode air blast freezing pada suhu sekitar $-36{ }^{\circ} \mathrm{C}$ (Diamante \& Tran, 2016) atau dengan pencelupan ke dalam nitrogen cair yang dapat mencapai suhu -196 sampai $-210{ }^{\circ} \mathrm{C}$ (Dewandari, Mulyawanti, \& Amiarsi, 2009). Proses pembekuan cepat membutuhkan teknologi yang cukup tinggi serta kebutuhan energi pendinginan yang besar.

Teknologi yang dinilai tepat untuk penanganan ikan di atas kapal dalam jangka waktu yang relatif tidak lama adalah dengan pendinginan pada suhu sekitar $0{ }^{\circ} \mathrm{C}$. Salah satu cara yang dapat dilakukan adalah dengan ALREF (air laut yang direfrigerasi) atau biasa juga disebut RSW (refrigerated sea water), yaitu dengan mendinginkan air laut yang akan digunakan untuk media pendinginan ikan. Metode ini dapat mengurangi resiko kerusakan fisik ikan yang biasanya terjadi pada penggunaan es akibat tekanan dan gesekan permukaan ikan dengan es. Proses pendinginan ini dapat berlangsung dengan cepat dan kelembaban permukaan ikan tetap terjaga, dengan demikian mutu dan kenampakan ikan dapat dipertahankan dalam kondisi baik. Dengan cara seperti ini seluruh permukaan ikan dapat berkontak langsung dengan media pendingin air es, termasuk rongga perut dan rongga insang. Cara ini cukup efisien untuk menurunkan suhu tengah tubuh ikan dalam waktu cepat (Wibowo, Utomo, Suherman, \& Putro, 2007). Penerapan ALREF menggunakan mesin pendingin pada kapal tuna longline di PPS Muara Baru Jakarta terbukti dapat mengurangi produk ikan tuna yang tidak memenuhi standar ekspor dari 50,4\% menjadi $21,5 \%$ (Nuraini, Murdaniel, \& Harahap, 2013). Dengan demikian, penerapan teknologi tersebut dapat meningkatkan kualitas hasil tangkapan tuna. Penerapan teknologi ALREF yang menggunakan mesin refrigerasi masih sangat terbatas digunakan pada kapal-kapal ukuran besar seperti hasil disain mesin pendingin pada kapal kayu 58 GT oleh Effendi dan Setiawan (2016). Instalasi komponen unit pendingin yang berukuran besar membutuhkan tempat yang luas serta kebutuhan energi pendinginan yang besar sehingga umumnya teknologi mesin pendingin hanya terdapat pada kapal kapal besar. Beberapa penelitian aplikasi sistem refrigerasi pada kapal kecil dan tradisional masih sangat terbatas di antaranya oleh Budiarto, Kiryanto dan Firmansyah (2013) yang merancang dan membuat mesin pendingin pada kapal Curik (panjang 7,8 $\mathrm{m}$ dan lebar 2,36 m) dengan kapasitas palka sebesar 0,095 $\mathrm{m}^{3}$.

Di sisi lain, jumlah kapal kecil dengan ukuran di bawah 30 GT cukup banyak, yaitu tercatat sekitar 72 buah kapal yang terdapat di PPP Cilacap dan PPP Sadeng. Sebagian besar kapal tersebut berukuran antara 10-15 GT yang belum menerapkan sistem refrigerasi untuk penyimpanan ikan. Ikan-ikan yang didaratkan oleh kapal tersebut sebagian mengalami kerusakan fisik terutama ikan hasil tangkapan pertama dan ikan-ikan yang tersimpan pada bagian bawah palka. Rancangan mini chilling storage untuk kapal menggunakan pendingin kompresi uap telah dilakukan oleh Widianto et al. (2016) yang telah menghasilkan rancangan mesin pendingin pada kapal 10-15 GT. Namun rancangan tersebut baru berupa kajian, analisis dan perhitungan matematis. Penelitian lanjutan dalam rangka menguji hasil rancangan perlu dilakukan untuk mengetahui performansi mesin pendingin untuk aplikasi ALREF pada kapal. Pada penelitian ini telah dihasilkan mesin pendingin untuk aplikasi ALREF pada kapal 10-15 GT untuk penyimpanan ikan serta dilakukan pengujian untuk mengetahui kinerja mesin pendingin yang dihasilkan. Penerapan teknologi ini diharapkan dapat membantu mengurangi kerusakan 
fisik pada ikan akibat beban es, membantu mengatasi masalah ketersediaan es, dan mengurangi beban angkut kapal pada saat menangkap ikan.

\section{BAHAN DAN METODE}

\section{Kriteria Disain}

Kriteria disain didapatkan berdasarkan hasil identifikasi kebutuhan mesin pendingin untuk aplikasi ALREF pada kapal penangkap ikan ukuran 10-15 GT yang diperoleh dari hasil pengamatan langsung di PPP Sadeng, Gunung Kidul, Yogyakarta dan PPS Cilacap, Jawa Tengah. Kriterianya antara lain: lama perjalanan kapal maksimal 7 hari, kapasitas optimal palka sebesar 1,3 ton ikan, dapat mempertahankan suhu ikan kurang dari $5^{\circ} \mathrm{C}$ (BSN, 2013), dan dapat diaplikasikan pada kapal 10-15 GT. Mesin pendingin digunakan untuk mendinginkan air laut di dalam palka kemudian digunakan untuk mendinginkan atau mempertahankan suhu ikan di bawah $5^{\circ} \mathrm{C}$. Sistem pendingin yang digunakan adalah sistem kompresi uap dengan sumber energi pengerak kompresor yang berasal dari mesin diesel yang tersedia di kapal. Motor diesel pada kapal 5-10 GT menggunakan 2 mesin diesel induk dengan spesifikasi 20-30 PK dan 1 buah mesin diesel untuk penerangan dengan sepesifikasi 8 PK.

\section{Beban Pendinginan}

Beban pendinginan terdiri dari beban pendinginan air laut, beban produk, beban panas sensible dinding palka, beban transmisi panas melalui dinding palka serta infiltrasi panas melalui tutup palka. Data perhitungan beban pendinginan diperoleh dari pengembangan perhitungan beban pendinginan pada rancangan mini chilling storage untuk kapal 10-15 GT (Widianto et al., 2016) dengan factor safety sebesar 40\%. Factor safetytersebut dengan mempertimbangkan jumlah tangkapan ikan pada musim puncak yang dapat mengangkut ikan sampai 1,9 ton. Perhitungan beban pendinginan total (dengan safety faktor $40 \%$ ) pada rancangan ini sebesar $5 \mathrm{~kW}$. Beban pendinginan yang berasal dari penggunaan keranjang plastik tempat meletakkan ikan diabaikan karena nilainya sangat kecil $(0,00052 \mathrm{~kW})$ dibandingkan dengan beban pendinginan total. Komposisi dan hasil perhitungan komponen beban pendinginan ditunjukkan pada Tabel 1.

\section{Rancangan Fungsional}

Rancangan fungsional mesin pendingin dikembangkan dari rancangan sistem thermal pada mini chilling strorage untuk kapal menggunakan pendingin kompresi uap (Widianto et al., 2016). Dari hasil penguraian fungsi-fungsi dari mesin pendingin yang dirancang (Tabel 2), maka air laut di dalam palka

Tabel 1. Hasil perhitungan beban pendinginan

Table 1. Cooling load calculation results

\begin{tabular}{lc}
\hline \multicolumn{1}{c}{ Beban pendinginan/Cooling load } & Nilai/Value (kW) \\
\hline Beban pendinginan total dengan factor safety 40\%/Total cooling load with factor & 5.00 \\
safety of 40\% & 3.63 \\
Beban pendinginan total/Total cooling load & 0.10 \\
Perpindahan panas melalui dinding/Heat transfer through walls & 0.51 \\
Panas sensibel ikan/Fish sensible heat & 0.10 \\
Panas sensibel dinding/Walls sensible heat & 2.62 \\
Panas sensibel air laut/Sea water sensible heat & 0.30 \\
Panas infiltrasi / Infiltration heat & \\
\hline
\end{tabular}

Tabel 2. Rancangan fungsional

Table 2. Functional design

\begin{tabular}{|c|c|}
\hline Fungsi/Functions & Bagian alat/Parts \\
\hline Menyimpan ikan/Storing the fish & Palka/Fish hold \\
\hline Mendinginkan ikan/Cooling the fish & Air laut/Sea water \\
\hline Refrigerant & Refrigerant R 22 \\
\hline Melepas panas ke lingkungan/Releasing heat to the environment & Evaporator \\
\hline Melepas panas dari refrigerant/Releasing heat from the refrigerant & Kondensor/Condenser \\
\hline Menaikkan tekanan refrigerant/Increasing refrigerant pressure & Kompresor/Compressor \\
\hline $\begin{array}{l}\text { Mengatur jumlah refrigerant yang mengalir ke evaporator/Controling the flow } \\
\text { rate of refrigerant that flows to evaporator }\end{array}$ & $\begin{array}{c}\text { Katup ekspansi/Expansion } \\
\text { valve }\end{array}$ \\
\hline
\end{tabular}


didinginkan menggunakan mesin pendingin yang terdiri dari beberapa komponen utama yaitu kondensor, kompresor, evaporator, dan katup ekspansi. Air laut dingin ini selanjutnya digunakan untuk mendinginkan ikan sampai suhu ikan terjaga di bawah $5{ }^{\circ} \mathrm{C}$. Komponen sistem pendingin untuk mendukung fungsinya masing-masing disajikan pada Tabel 2.

\section{Analisis Siklus Refrigerasi}

Data perhitungan siklus refrigerasi dalam pemilihan spesifikasi komponen pendingin serta hasil perhitungannya ditampilkan dalam Tabel 3. Data tersebut digunakan sebagai dasar pemilihan komponen cooling unit.

\section{Bahan}

Bahan yang digunakan dalam rancang bangun mesin pendingin adalah baja profil $\mathrm{H}(100 \times 100 \times 3 \mathrm{~mm})$, fiberglass, stirofoam, kayu, pipa tembaga $5 / 8$ inchi tebal $1,6 \mathrm{~mm}$, kondensor shell and tube Alfalaval McDEW 25, kompresor Blitzer Tipe LH IVY, refrigerant R-22, selang air $3 / 4$ inch, pompa air, komponen kelistrikan, katup ekspansi dan aksesories cooling unit lainya. Bahan yang digunakan untuk uji kinerja alat adalah air, garam dan ikan nila. Ikan nila dipilih sebagai pengganti ikan laut karena dalam pengujian sulit untuk mendapatkan ikan laut hasil tangkapan pada hari pertama. Ikan nila diperoleh dalam keadaan hidup kemudian dibiarkan di atas keranjang tanpa air sampai mati (sekitar 30 menit). Ikan nila yang digunakan mempunyai berat antara 250-300 g/ekor. Peralatan yang digunakan dalam proses rancang bangun alat dan pengujian adalah mesin penekuk, pengerol, alat las, gerinda, alat potong, termometer dan peralatan bengkel lainnya.

\section{Pemilihan Kompresor dan Kondensor}

Pemilihan kompresor dilakukan berdasarkan perhitungan kebutuhan kerja kompresor sebesar 1,65 kW. Nilai tersebut didapatkan berdasarkan perhitungan kerja kompresor (Tabel 3) sebesar 1,48 kW dengan mempertimbangkan efisiensi kompresor dengan estimasi sebesar $90 \%$. Kompresor yang sesuai dengan spesifikasi tersebut serta digunakan untuk aplikasi di laut adalah Bitzer LH IVY dengan kebutuhan daya sekitar 3 HP. Spesifikasi kompresor Bitzer LH IVY yang digunakan ditunjukkan pada Tabel 4 .

Pemilihan kondensor berdasarkan analisis perhitungan kalor yang diperoleh pada siklus refrigerasi, ketersediaan di pasar, spesifikasi dan tempat pengaplikasian kondensor (lingkungan laut). Tipe kondensor yang dipilih adalah shell and tube dengan bahan $\mathrm{Cu}-\mathrm{Ni}$ dengan pendingin air laut. Pemilihan bahan Cu-Ni untuk menghindari perkaratan pipa akibat penggunaan pendingin air laut yang disirkulasikan serta memiliki konduktivitas termal yang

Tabel 3. Perhitungan siklus refrigerasi

Table 3. Calculations of refrigeration cycle

\begin{tabular}{lc}
\hline \multicolumn{1}{c}{ Parameter/Parameters } & Unit/Units \\
\hline Beban pendinginan/Cooling load & $5 \mathrm{~kW}$ \\
Suhu evaporator/Evaporator temperature & $-8{ }^{\circ} \mathrm{C}$ \\
Tekanan evaporator pada $-8^{\circ} \mathrm{C} /$ Evaporator pressure at $-8{ }^{\circ} \mathrm{C}$ & $380.5 \mathrm{kPa}$ \\
Superheated vapor & $5{ }^{\circ} \mathrm{C}$ \\
Suhu kondensor/Condenser temperature & $40{ }^{\circ} \mathrm{C}$ \\
Tekanan kondensor pada $40^{\circ} \mathrm{C} /$ Condenser pressure at $40^{\circ} \mathrm{C}$ & $1534 \mathrm{kPa}$ \\
Subcooling refrigerant & $35^{\circ} \mathrm{C}$ \\
Panas laten pada -20 ${ }^{\circ} \mathrm{C} /$ Latent heat at $-20{ }^{\circ} \mathrm{C}$ & $211.3 \mathrm{~kJ} / \mathrm{kg}$ \\
Kerja kompresi/Compression work & $46.6 \mathrm{~kJ} / \mathrm{kg}$ \\
Efek refrigerasi/Refrigeration effect & $162.57 \mathrm{~kJ} / \mathrm{kg}$ \\
Laju pelepasan kalor/Heat release rate & $209.17 \mathrm{~kJ} / \mathrm{kg}$ \\
COP & 3.5 \\
Laju aliran refrigerant/Refrigerant flow rate & $1.91 \mathrm{~kg} / \mathrm{menit} / \mathrm{minutes}$ \\
Kerja kompresor/Work of compressor & $1.48 \mathrm{~kW}$ \\
Pelepasan kalor kondensor/Condenser heat release & $6.7 \mathrm{~kW}$ \\
Daya per kW refrigerasi/Ratio of refrigeration power & $0.33 \mathrm{~kW} / \mathrm{kW}$ \\
\hline
\end{tabular}


Tabel 4. Spesifikasi kompresor Bitzer LHIVY

Table 4. Bitzer LHIVY compressor specification

\begin{tabular}{lc}
\hline \multicolumn{1}{c}{ Spesifikasi/Specification } & Unit/Units \\
\hline Daya/Power & $3 \mathrm{HP}$ \\
Kapasitas aliran/Flow capacity & $7.3-14.9 \mathrm{~m}^{3} / \mathrm{jam} /$ hours \\
Tekanan maksimal/Maximum pressure & $19-23 \mathrm{bar}$ \\
RPM & $370-750 \mathrm{rpm}$ \\
Diameter puli/Pulley diameter & $15 \mathrm{inchi}$ \\
\hline
\end{tabular}

Tabel 5. Spesifikasi kondensor Alfalaval McDEW 25

Table 5. Alfalaval McDEW 25 condenser specification

\begin{tabular}{lc}
\hline \multicolumn{1}{c}{ Spesifikasi/Specification } & Unit/Units \\
\hline Kapasitas maksimal/Maximum capacity & $24.5 \mathrm{~kW}$ \\
Suhu kondensasi/Condensing temperature & $43^{\circ} \mathrm{C}$ \\
Water inlet temperature & $29.4{ }^{\circ} \mathrm{C}$ \\
Fouling factor & $0.000043 \mathrm{~m}^{2} . \mathrm{K} / \mathrm{W}$ \\
Penurunan tekanan/Presure drop & $0.21 \mathrm{bar}$ \\
Nominal water flow rate & $2.4 / 2.88 \mathrm{~m}^{3} / \mathrm{jam} /$ hours \\
\hline
\end{tabular}

baik. Berdasarkan jumlah kalor yang dikeluarkan pada kondensor sebesar 6,7 kW (Tabel 3) yang diperoleh dari hasil perhitungan (perkalian antara laju pelepasan kalor dengan aliran refrigerant), maka digunakan kondensor Alfalaval McDEW 25 dengan spesifikasi ditunjukkan pada Tabel 5.

\section{Evaporator dan Palka}

Rancangan struktur palka dikembangkan dari rancangan Widianto et al. (2016) berbentuk kotak dengan ukuran (PxLxT) yaitu 1,6 x 1,2 x 1,1 meter.
Ukuran tersebut berdasarkan spesifikasi geladak kapal yang memungkinkan untuk ditempatkan palka. Dinding palka terbuat dari bahan fiberglass dengan insulator menggunakan stirofoam high density (densitas sekitar $34 \mathrm{~kg} / \mathrm{m}^{3}$ ) dengan tebal $7 \mathrm{~cm}$. Evaporator yang digunakan adalah tipe bare tube yang dipasang mengelilingi dinding palka. Evaporator terdiri dari susunan pipa dari bahan tembaga yang berfungsi untuk mendinginkan air laut secara langsung di dalam palka (Gambar 1). Evaporator tipe ini mudah dalam perawatan dan dapat menyerap panas udara dalam

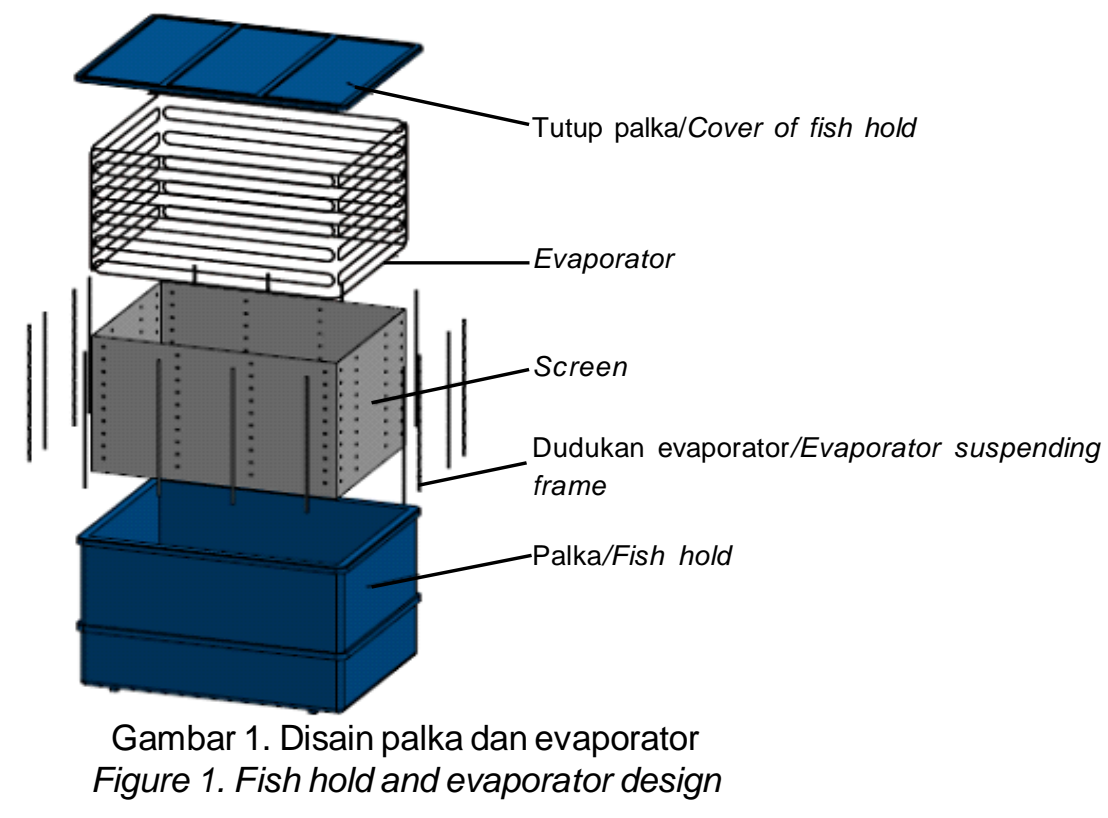




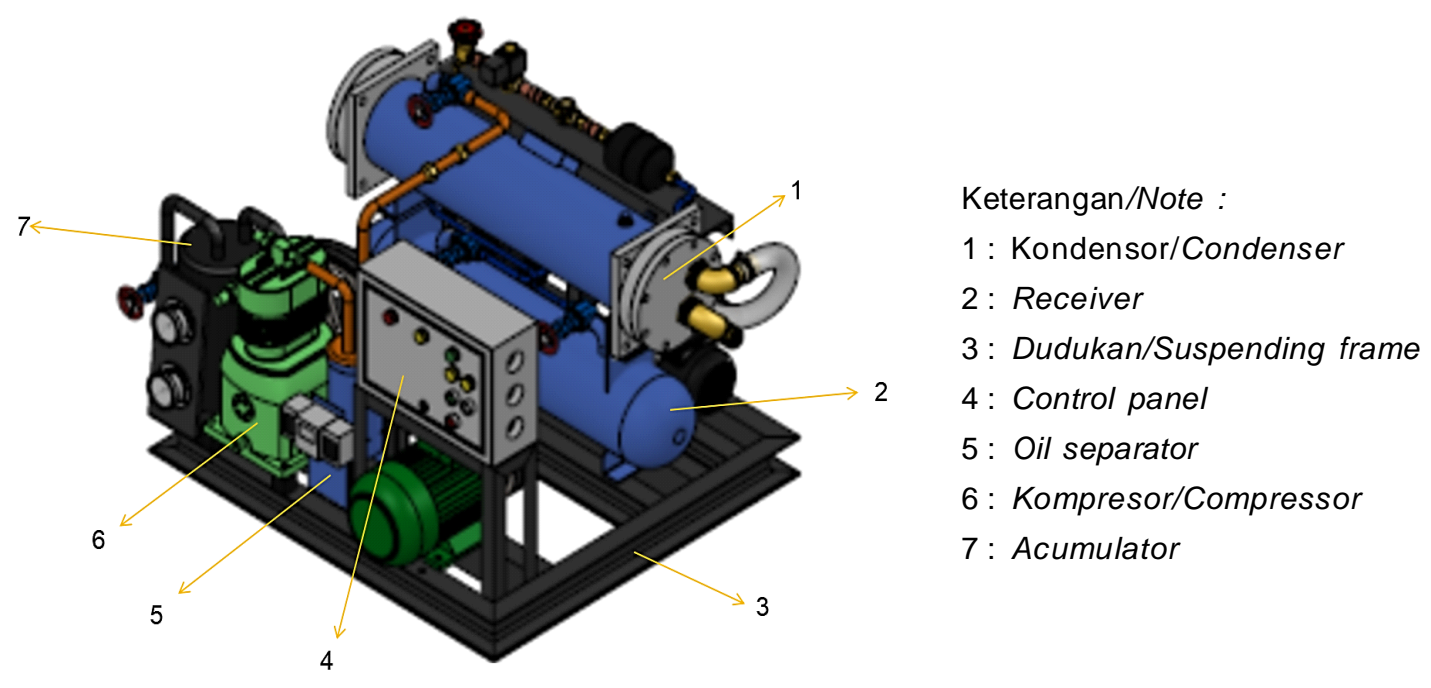

Gambar 2. Disain komponen pendingin

Figure 2. Cooling unit design

palka secara langsung. Screen ditambahkan untuk melindungi evaporator dari kontak langsung dengan ikan. Screen terbuat dari lembaran fiberglass berpori dengan jumlah pori sebanyak 100 lubang $/ \mathrm{m}^{2}$ dengan diameter pori sebesar $15 \mathrm{~mm}$. Air laut dalam palka didinginkan oleh pipa palka evaporator sampai suhu mencapai $-1^{\circ} \mathrm{C}$. Disain evaporator menggunakan pipa tembaga dengan tebal 1,6 $\mathrm{mm}$, panjang 84 meter dan diameter 5/8 inchi. Gambar rancangan palka dan evaporator ditunjukkan pada Gambar 1.

\section{Metode Uji Kinerja Mesin}

Uji kinerja mesin dilakukan untuk mengetahui apakah mesin pendingin yang dirancang dapat bekerja sesuai kriteria disain yang telah ditentukan. Uji kinerja dilakukan dua kali dengan menguji sistem pendingin (1) dengan beban pendinginan air laut dan (2) dengan beban ikan. Pengujian dilakukan di Loka Riset Mekanisasi Pengolahan Hasil Perikanan, Bantul, DI Yogyakarta.

Pengujian pertama dilakukan dengan mendinginkan air laut sebanyak $910 \mathrm{~kg}$ di dalam palka selama 8,5 jam. Parameter pengamatan meliputi suhu air laut, suhu udara dalam palka, suhu air masuk dan keluar kondensor serta suhu pipa evaporator. Selama pengujian, palka dalam kondisi tertutup. Pengukuran suhu air laut dilakukan pada posisi tengah bagian yang terisi air laut dan pengukuran suhu udara palka dilakukan pada posisi rongga tengah ruang palka yang tidak terisi air laut. Pengukuran suhu air masuk dan keluar kondensor dilakukan pada ujung pipa saluran air masuk dan keluar kondensor. Pengukuran suhu evaporator dilakukan pada permukaan pipa evaporator bagian tengah. Pengukuran suhu dilakukan secara manual tiap 30 menit menggunakan termometer digital dengan dua kali ulangan pengukuran. Selain itu dilakukan pengukuran kebutuhan daya listrik sistem yang dilakukan dengan mengukur jumlah arus listrik yang melalui sistem secara manual menggunakan multitester digital tiap 30 menit. Pengujian dilakukan sebanyak dua kali ulangan pengujian (pengujian I dan pengujian II)

Pengujian kedua dilakukan dengan beban ikan dengan palka tertutup. Pengujian ini bertujuan untuk mengetahui capaian suhu ikan selama penyimpanan di dalam palka. Pengujian dilakukan dengan menyimpan ikan nila sebanyak $30 \mathrm{~kg}$ sebagai uji awal dengan berat antara 200-350 g/ekor di dalam palka. Penggunaan ikan nila dilakukan karena kelimpahan dan kemudahan memperolehnya dalam kondisi segar. Uji awal dimaksudkan untuk mengetahui perubahan suhu ikan selama penyimpanan selama 5 hari.

Ikan nila dimasukkan ke dalam keranjang kemudian keranjang diikat agar posisi ikan selama pengujian tidak berubah sehingga memudahkan dalam pengamatan. Ikan nila dimasukkan setelah suhu air laut dalam palka mencapai kisaran -1 sampai $1^{\circ} \mathrm{C}$ kemudian palka ditutup dan dilakukan pengamatan. Pengujian ini dilakukan selama 5 hari penyimpanan dengan parameter yang diukur adalah suhu pusat ikan nila dan suhu air laut yang dilakukan tiap 12 jam menggunakan termometer digital dengan dua kali ulangan pengujian (pengujian I dan pengujian II). Selama pengujian mesin pendingin dimatikan jika suhu air laut telah mencapai $-1^{\circ} \mathrm{C}$ dan dinyalakan kembali saat suhu air laut naik mendekati $3^{\circ} \mathrm{C}$. 


\section{HASIL DAN PEMBAHASAN}

Hasil konstruksi palka dan rangkaian mesin pendingin ditunjukkan pada Gambar 2. Kegiatan pengujian dengan beban air dan beban ikan ditunjukkan pada Gambar 3. Hasil pengujian dengan beban air laut menunjukkan bahwa selama 8,5 jam pengujian, suhu air sudah mencapai kisaran -0,4 sampai $-0,8^{\circ} \mathrm{C}$ seperti ditunjukkan pada Gambar 5 .

Suhu udara dalam palka selama pengujian mencapai kisaran $-1,2$ sampai $-1,8^{\circ} \mathrm{C}$. Suhu udara dan air pada awal pengujian sekitar $25-27,7^{\circ} \mathrm{C}$ dengan suhu lingkungan selama pengujian berkisar 27,9 - 31,9 ${ }^{\circ} \mathrm{C}$. Panas air laut dalam palka dipindahkan ke refrigerant secara konveksi dan konduksi. Perpindahan panas terjadi antara air laut dengan dinding pipa evaporator selanjutnya dipindahkan ke refrigerant. Perpindahan panas secara konveksi terjadi antara fluida dengan permukaan pipa evaporator (Rohsenow, Hartnett \& Cho, 1998). Sedangkan secara konduksi perpindahan panas terjadi pada dinding evaporator, di mana perpindahan panas secara konduksi terjadi akibat adanya perbedaan suhu pada material dengan memenuhi kaidah hukum Fourier (Lienhard IV \& Lienhard V, 2017).

Capaian suhu udara ruang palka dan suhu air laut selama pengujian tidak jauh berbeda. Hal ini menunjukkan bahwa perpindahan panas antara udara dengan air secara konveksi dapat berlangsung dengan baik. Setelah 6 jam pengujian, suhu air laut sudah mencapai di bawah $5^{\circ} \mathrm{C}$, sehingga sudah mulai dapat dipergunakan untuk penyimpanan ikan dengan terus menyalakan mesin pendingin sampai target suhu air laut mencapai $-1^{\circ} \mathrm{C}$. Pengujian suhu air laut pada rancang bangun mesin pendingin kapal tradisional oleh Budiarto et al. (2013) menunjukkan bahwa suhu air laut mencapai $0^{\circ} \mathrm{C}$ selama kurang lebih 4,7 jam. Palka yang digunakan pada penelitian tersebut mempunyai kapasitas sebesar $0,095 \mathrm{~m}^{3}$. Perbedaan capaian suhu
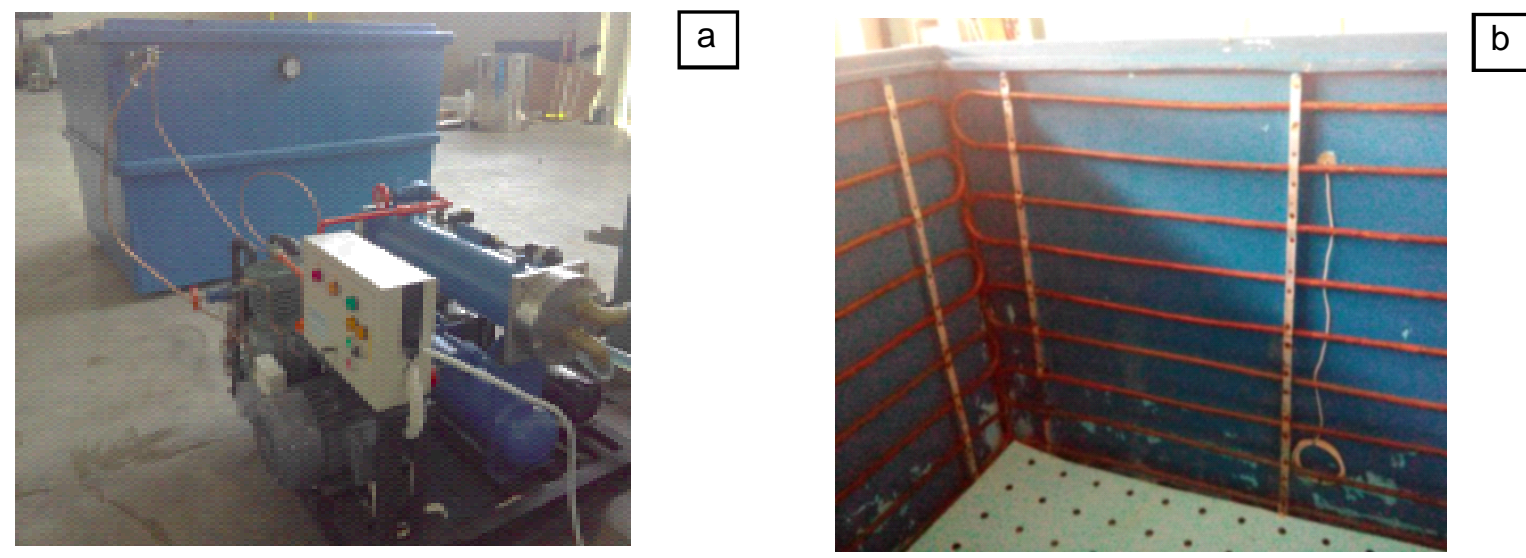

Gambar 3. Palka dan cooling unit (a), dan evaporator dalam palka (b)

Figure 3. Fish hold and cooling units (a), and evaporator at fish hold (b)
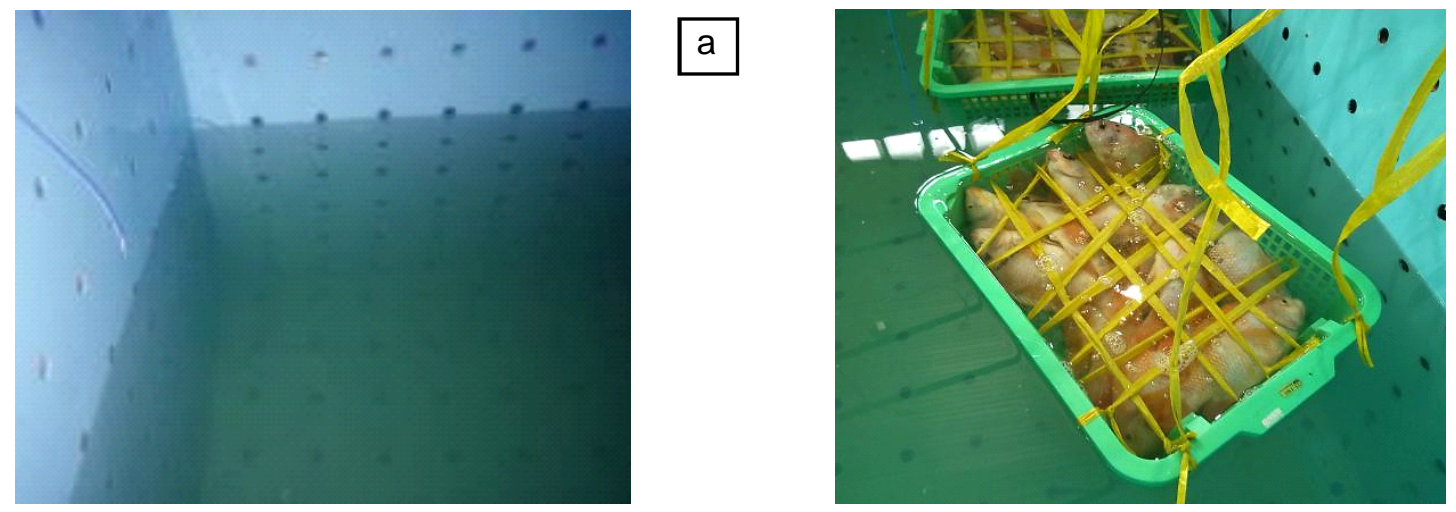

Gambar 4. Uji kinerja mesin pendingin dengan beban air (a) dan ikan (b) Figure 4. Performance test of cooling units loaded with water (a) and fish (b) 


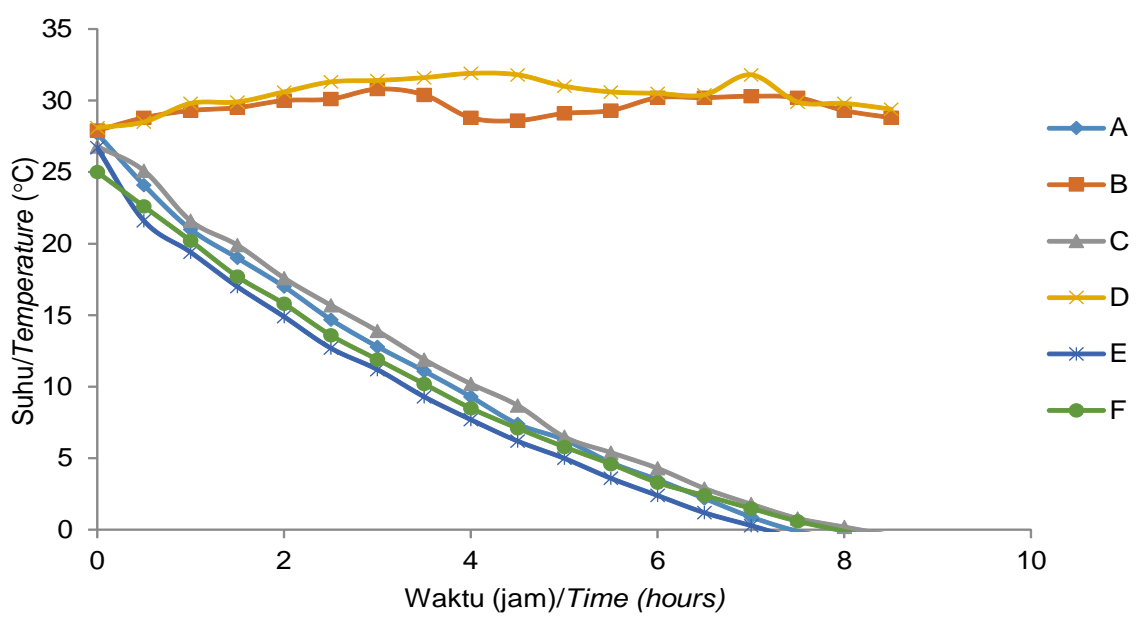

Keterangan/Note :

A : Suhu udara dalam palka pada pengujian I dengan air laut/Air temperature in the fish hold from $1^{\text {st }}$ performance test loaded with sea water

B : Suhu udara lingkungan pada pengujian I dengan air laut/Ambient temperature from $1^{\text {st }}$ performance test loaded with sea water

C : Suhu air pada pengujian I dengan air laut/Water temperature in the fish hold from $1^{\text {st }}$ performance test loaded with sea water

D : Suhu udara lingkungan pada pengujian II dengan air laut/Ambient temperature $2^{\text {nd }}$ performance test loaded with sea water

$\mathrm{E}$ : Suhu udara dalam palka pada pengujian II dengan air laut/Air temperature in the fish hold from $2^{\text {nd }}$ performance test loaded with sea water

F : Suhu air pada pengujian II dengan air laut/Water temperature in the fish hold from $2^{\text {nd }}$ performance test loaded with sea water

Gambar 5. Suhu air, udara dan lingkungan selama pengujian dengan air laut

Figure 5. Water, air and ambient temperature during performance testing loaded with sea water

air dalam palka selain disebabkan oleh perbedaan spesifikasi palka, juga disebabkan oleh beberapa hal antara lain spesifikasi mesin pendingin serta jumlah beban air laut yang dipergunakan. Jika dibandingkan dengan capaian suhu pipa evaporator (Gambar 6), maka terjadi perbedaan suhu yang cukup besar. Pada jam ke-8 suhu pipa evaporator telah mencapai $-28^{\circ} \mathrm{C}$, sedangkan suhu air $-0,8^{\circ} \mathrm{C}$. Perbedaan capaian suhu air laut dan dinding pipa evaporator disebabkan oleh penyerapan panas air laut menuju pipa evaporator terjadi secara konveksi alami yang sangat tergantung dari besarnya luas penampang evaporator, jumlah air

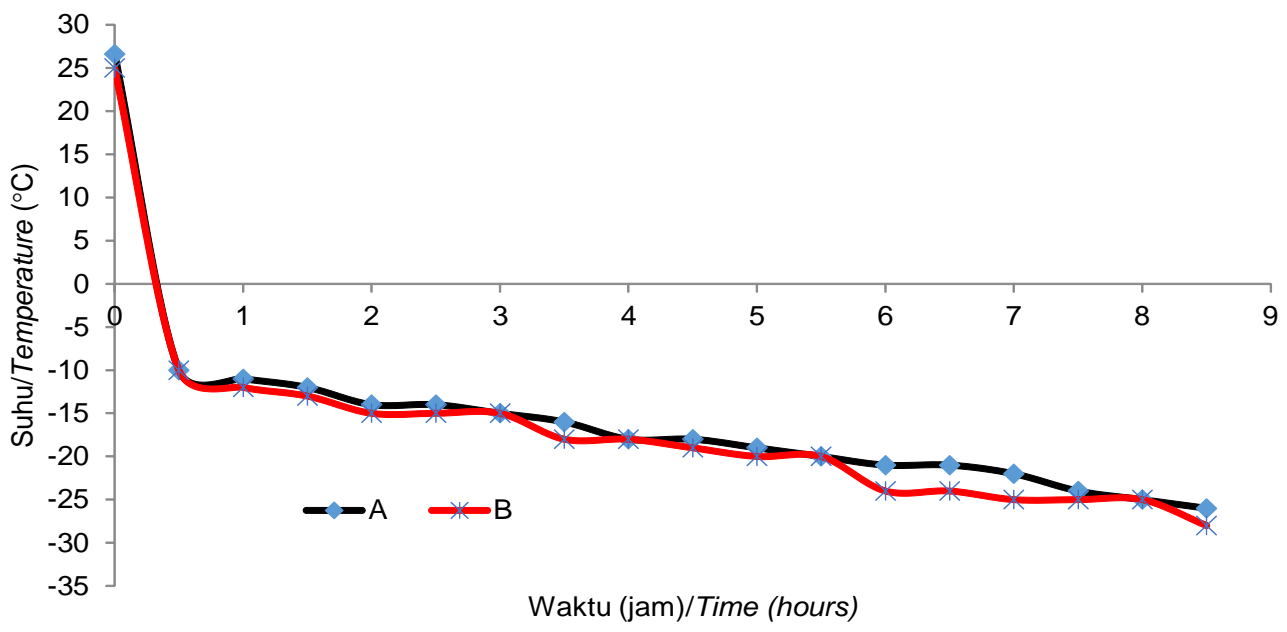

Keterangan/Note:

$\mathrm{A}$ : pengujian $\mathrm{I} / 1^{\text {st }}$ performance test

$\mathrm{B}$ : pengujian II/ $2^{\text {nd }}$ performance test

Gambar 6. Suhu evaporator selama pengujian dengan beban air laut

Figure 6. Evaporator temperature during performance testing loaded with sea water 
serta jarak antara permukaan evaporator (suhu dingin) dengan pusat pengukuran suhu air (suhu panas). Alternatif yang dapat dilakukan untuk mengatasi kendala tersebut adalah dengan melakukan sirkulasi air sehingga perpindahan panas dapat terjadi secara konveksi paksa. Perpindahan panas dari air laut menuju refrigerant melalui pipa evaporator sangat ditentukan oleh besarnya koefisien perpindahan total serta luas bidang evaporator yang bersentuhan dengan air laut. Perpindahan kalor antara fluida dengan dinding evaporator terjadi secara konveksi (Jiji, 2006). Perpindahan kalor secara konveksi dapat dipercepat dengan bantuan aliran fluida dengan menambahkan pompa untuk mensirkulasi air laut. Dengan demikian, pemberian sirkulasi air akan memperbaiki performa alat.

Tipe evaporator lainnya dalam refrigerasi di atas kapal adalah tipe shell and tube dengan mengalirkan air laut secara sirkulasi dari evaporator menuju palka. Tipe evaporator ini memungkinkan perpindahan panas antar fluida dapat berlangsung dengan cepat, namun penggunaan evaporator tipe shell and tube membutuhkan ruang yang lebih luas serta komponen mesin yang lebih banyak sehingga kurang sesuai diaplikasikan pada kapal yang berukuran kecil. Dasar pemilihan tipe evaporator pada rancangan ini lebih dititikberatkan pada kemudahan perawatan, konstruksi, kemudahan pengoperasian mesin serta disain akhir refrigerasi yang sederhana dan mudah diaplikasikan pada kapal ukuran 10-15 GT. Evaporator tipe bar and tube pada rancangan ini menghasilkan sistem refrigerasi yang sederhana, mudah dioperasikan, mudah dalam perawatan serta tidak membutuhkan ruang yang luas sehingga sesuai untuk diaplikasikan pada kapal kecil. Sistem ini perlu penambahan pompa untuk mensirkulasikan air dalam palka secara efektif agar perpindahan panas beban menuju evaporator terjadi lebih cepat.

Hasil pengukuran suhu air pada kondensor terlihat pada Gambar 7. Hasil pengukuran suhu air menunjukkan pola yang sama antara pengujian I dengan pengujian II. Pada satu jam pertama terlihat bahwa suhu air cenderung naik kemudian stabil pada jam berikutnya. Data ini menunjukkan bahwa pada awal pengujian terjadi perpindahan panas yang cukup besar. Hal ini sesuai dengan capain suhu pada evaporator yang turun dengan cepat pada awal pengujian (Gambar 6).

Penelitian pada beberapa sistem pendingin yang lain juga menunjukkan hal yang sama, di awal

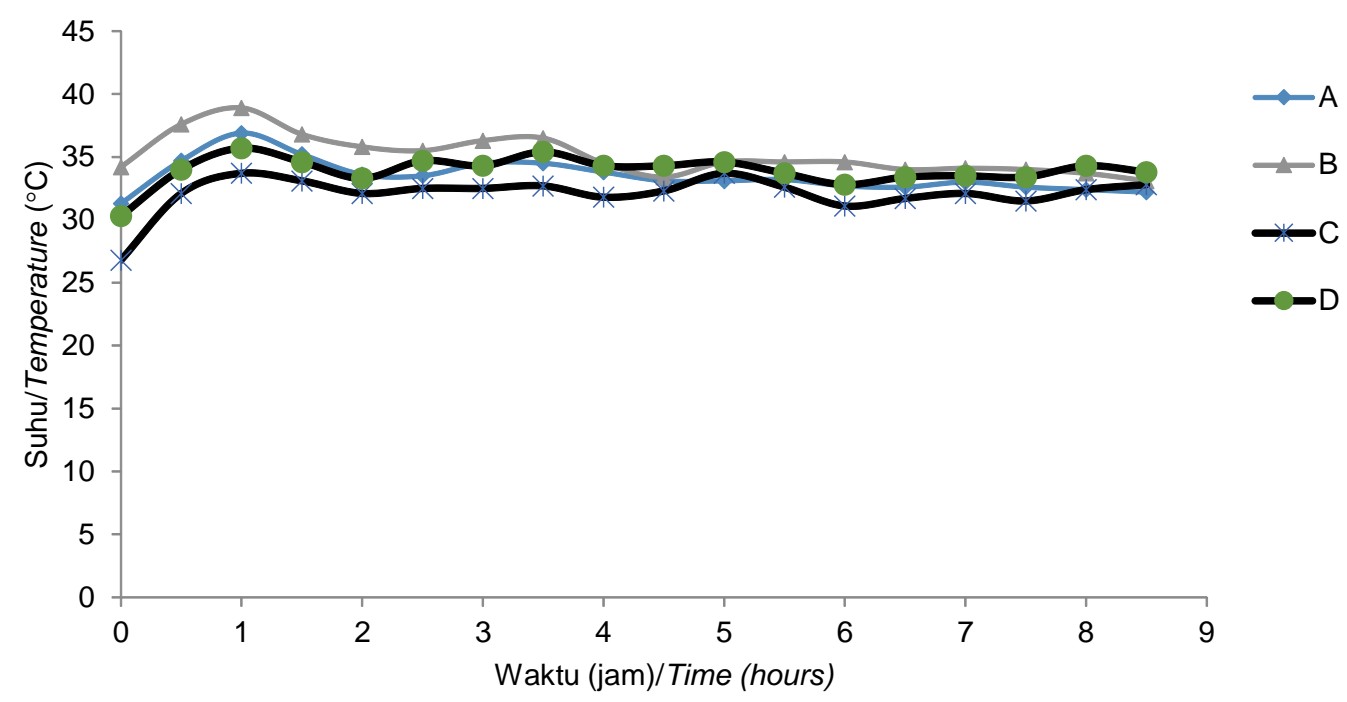

Keterangan/Note :

A : suhu air masuk kondensor pada pengujian I dengan air laut/condenser water inlet temperature from $1^{\text {st }}$ performance test loaded with sea water

B : suhu air keluar kondensor pada pengujian I dengan air laut/condenser water outlet temperature from $1^{\text {st }}$ performance test loaded with sea water

C : suhu air masuk kondensor pada pengujian II dengan air laut/condenser water inlet temperature from $2^{\text {nd }}$ performance test loaded with sea water

D : suhu air keluar kondensor pada pengujian II dengan air laut/condenser water outlet temperature from $2^{\text {nd }}$ performance test loaded with sea water

Gambar 7. Suhu air kondensor selama pengujian dengan beban air laut

Figure 7. Condenser water temperature during performance testing loaded with sea water 


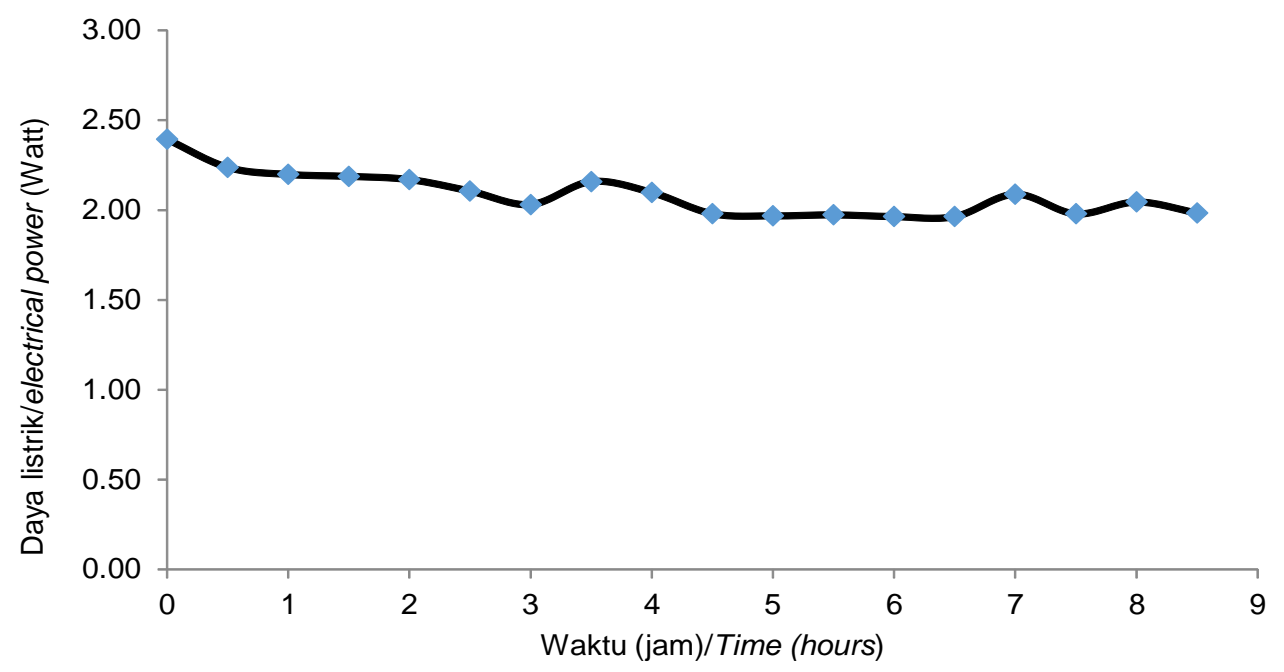

Gambar 8. Kebutuhan daya listrik rata-rata mesin pendingin

Figure 8. Average electrical power consumption of cooling units

pengujian penurunan suhu ruang pendingin lebih cepat kemudian konstan pada jam berikutnya (Widianto \& Sedayu, 2015). Adanya perbedaan suhu air masuk dan keluar pada kondensor yang berkisar $1,6-1,8^{\circ} \mathrm{C}$ menunjukkan terjadinya pelepasan kalor dari kondensor ke air. Selain spesifikasi kondensor, pelepasan panas sangat dipengaruhi oleh debit aliran air pendingin. Parameter tersebut sangat menentukan besaran koefisien perpindahan panas total pada kondensor. Penelitian terkait hal tersebut salah satunya disampaikan oleh Thirumarimurugan, Kannadasan, dan Ramasamy (2008). Volume debit yang semakin besar dapat meningkatkan efektifitas perpindahan panas pada shell and tube heat exchanger.

Hasil pengujian kebutuhan daya pendinginan ratarata juga menunjukkan hal yang sama. Pada awal pengujian, sistem membutuhkan daya yang lebih tinggi kemudian konstan pada jam pengujian berikutnya (Gambar 8). Kebutuhan daya mesin pendingin pada awal pengujian sebesar $2,4 \mathrm{~kW}$, sedangkan pada pengujian jam berikutnya rata-rata hanya sekitar $2 \mathrm{~kW}$. Kebutuhan energi rata-rata yaitu sebesar $2 \mathrm{~kW}$ sesuai dengan ketersediaan sumber energi pada kapal hingga ukuran 15 GT. Kapal pada ukuran tersebut menggunakan energi yang bersumber dari mesin diesel sekitar 20-30 kW sebanyak dua buah sebagai mesin induk, serta $8 \mathrm{~kW}$ sebagai lampu penerang. Kebutuhan energi mesin pendingin sebesar $2 \mathrm{~kW}$ dapat diambil dari mesin diesel lampu penerangan, sehingga tidak perlu menambahkan mesin diesel lagi.

Data pengukuran suhu ikan nila dan air laut selama pengujian ditunjukkan pada Gambar 9. Suhu ikan turun dengan cepat mencapai kisaran $-0,1$ sampai $-1^{\circ} \mathrm{C}$ selama 12 jam pengujian, kemudian konstan pada pengujian berikutnya. Capaian suhu ikan, selain suhu media pendingin juga dipengaruhi oleh berat ikan. Jain dan Pathere (2007) melakukan pengukuran koefisien difusi panas pada ikan yang nilainya bervariasi tergantung dari massa ikan. Pada kondisi tersebut ALREF dapat mempertahankan suhu ikan selama pengujian sehingga sesuai persyaratan suhu penyimpanan ikan. Persyaratan yang berlaku menyatakan bahwa penanganan ikan segar selama transportasi dan penyimpanan dilakukan pada suhu di bawah $5^{\circ} \mathrm{C}$ (BSN, 2013). Pengujian transportasi ikan tuna pada suhu rendah (di bawah $3^{\circ} \mathrm{C}$ ) dapat mempertahankan mutu ikan selama waktu transportasi (Widianto, Hermawan, \& Utomo, 2014). Penerapan mesin pendingin untuk ALREF pada aplikasi penyimpanan ikan hasil tangkapan nelayan dapat menggunakan metode pengoperasian yang berbeda-beda, terutama durasi waktu pengoperasian mesin pendingin. Hal ini dimungkinkan karena adanya variasi jenis ikan, karakteristik fisik serta komposisi ikan yang akan menyebabkan perbedaan nilai koefisien perpindahan panas ikan. Penelitian pendinginan ikan menggunakan es juga menunjukkan bahwa semakin besar ukuran ikan akan semakin kecil nilai koefisien perpindahan panas (Jain, Pathare, Prasad, \& Singh, 2005) sehingga membutuhkan waktu pendinginan yang lebih lama jika dibandingkan dengan ikan yang lebih kecil. Oleh karena itu pada praktek di lapangan, durasi mesin pendingin dihidupkan akan sangat tergantung dengan jumlah dan ukuran hasil tangkapan. Makin besar jumlah dan ukuran ikan akan membutuhkan waktu lebih lama saat mesin pendingin dalam kondisi menyala dan tergantung kondisi capaian suhu air laut selama 


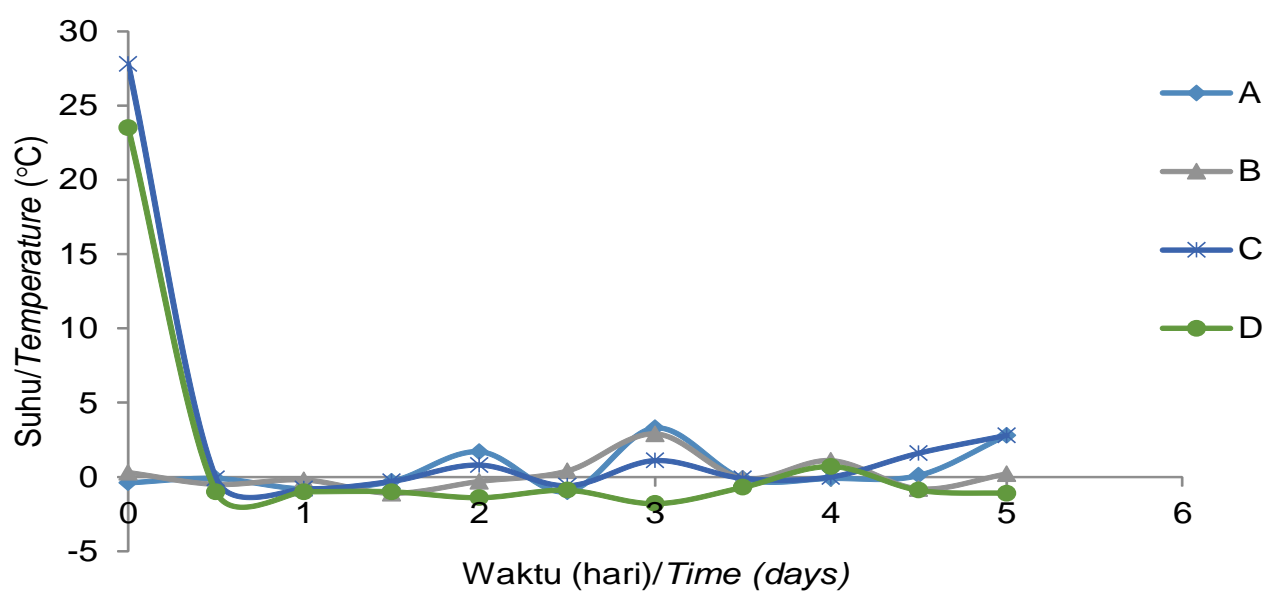

Keterangan/Note :

A : suhu air pada pengujian I dengan beban ikan/water temperature from $1^{\text {st }}$ performance test loaded with fish B : suhu air pada pengujian II dengan beban ikan/water temperature from $2^{\text {nd }}$ performance test loaded with fish C : suhu ikan pada pengujian I dengan beban ikan/fish temperature from $1^{\text {st }}$ performance test loaded with fish $\mathrm{D}$ : suhu ikan pada pengujian II dengan beban ikan/fish temperature from $2^{\text {nd }}$ performance test loaded with fish

Gambar 9. Suhu ikan dan air selama pengujian dengan beban ikan Figure 9. Fish and water temperature at performance test with loaded fish

kegiatan penyimpanan ikan. Pada penyimpanan ikan pada uji kinerja alat ini digunakan keranjang plastik untuk mencegah ikan berpindah posisi selama pengujian sehingga dapat memudahkan proses pengambilan data selama pengujian. Penambahan keranjang tersebut tidak mempengaruhi capaian suhu ikan selama pengujian, karena dari hasil penghitungan beban pendinginan yang berasal dari keranjang plastik nilainya sangat kecil $(0,0005 \mathrm{~kW})$ jika dibandingkan dengan beban pendinginan total sebesar $5 \mathrm{~kW}$.

Pengukuran suhu ikan dan air laut selama pengujian menghasilkan nilai yang tidak jauh berbeda. Hal ini menunjukkan bahwa proses perpindahan panas antara ikan dengan media pendingin dapat berjalan dengan baik. Uji kinerja dengan beban ikan selama 5 hari menunjukkan bahwa suhu ikan turun dari $27,8^{\circ} \mathrm{C}$ menjadi berkisar $-0,1$ sampai $-1^{\circ} \mathrm{C}$ setelah 12 jam dan dapat dipertahankan selama pengujian. Hasil pengukuran suhu air laut selama pengujian pada beberapa pengukuran menunjukkan nilai yang lebih tinggi dari pada suhu ikan. Hal ini disebabkan oleh posisi pengukuran suhu air yang berada di tengah palka, sedangkan posisi ikan di tepi palka (lebih dekat dengan posisi evaporator), sehingga capaian suhu ikan pada posisi pinggir akan lebih dingin dibanding suhu air di tengah pada saat pengukuran. Selain itu, mesin pendingin hanya dihidupkan saat suhu air laut naik mendekati $3^{\circ} \mathrm{C}$ dan dimatikan saat suhu air mencapai $-1^{\circ} \mathrm{C}$. Hal tersebut juga menyebabkan suhu air laut dan ikan naik turun.

\section{KESIMPULAN}

Hasil uji kinerja mesin pendingin dengan beban air laut menunjukkan bahwa suhu air laut mencapai kisaran - 0,4 sampai $-0,8^{\circ} \mathrm{C}$ selama 8,5 jam dan selanjutnya dapat dipergunakan untuk menyimpan ikan. Kebutuhan energi mesin pendingin maksimal $2,4 \mathrm{~kW}$ dengan rata-rata sebesar $2 \mathrm{~kW}$. Pengujian penyimpanan ikan nila dalam ALREF menggunakan mesin pendingin selama 5 hari menunjukkan suhu ikan turun dari $27,8^{\circ} \mathrm{C}$ menjadi $-1^{\circ} \mathrm{C}$ setelah 12 jam dan dapat dipertahankan selama pengujian. Penggunaan ALREF untuk penyimpanan ikan hasil tangkapan nelayan menggunakan metode pengoperasian mesin pendingin berbeda-beda, terutama durasi pengoperasian mesin pendingin selama proses penyimpanan ikan. Optimalisasi rancangan mesin pendingin pada penelitian ini dapat dilakukan dengan menambahkan pompa untuk mensirkulasikan air dalam palka secara efektif agar perpindahan panas beban menuju evaporator terjadi lebih cepat.

\section{DAFTAR PUSTAKA}

Badan Standardisasi Nasional (BSN). (2013). SNI 27292013. Ikan Segar.

Badan Standardisasi Nasional (BSN). (2006). SNI 012693.2-2006. Tuna segar untuk sashimi Bag 2 : Persyaratan bahan baku. 
Budiarto, U., Kiryanto, \& Firmansyah, H.(2013). Rancang bangun sistem refregerated sea water untuk kapal nelayan tradisional. Kapal. 10(1), 48-57.

Diamante, L.M., \& Tran, N.T.M. (2016). Effects of meat shape and size, freezing method and thawing temperature on the drip loss of beef brisket and the protein content of its thaw exudates. Journal of Food Chemistry \& Nanotechnology. 2(1), 14-20.

Dewandari,K.T., Mulyawanti, I., \& Amiarsi, D. (2009). Pembekuan cepat puree mangga arumanis dan karakteristiknya selama penyimpanan. Jurnal Pascapanen. 6(1), 27-33.

Effendi, R., \& Setiawan, I. (2016). Perancangan refregerated sea water (RSW) sistem kering pada ikan kaku lapis fiber 58 GT dengan kapasitas palka $45 \mathrm{~m}^{3}$. Sintek. 10(2), 56-66.

Jiji, L.M., (2006). Heat convection. Newyork. Spriger.

Jain, D. S. M., Pathare, P. B., Prasad, S., \& Singh, H. (2005). Development of mathematical model for cooling. Journal of food engineering. 71(25), 324329

Jain, D., \& Pathere, P. B. (2007).Determination of thermal diffusivity of freshwater fish during ice storage by using one-dimentional fourier cylindrical equation. Biosystems Engineering. 96(3), 407-412

Lienhard IV, J. H., \& Lienhard V, J. H. (2017). A heat transfer textbook $\left(4^{\text {th }} e d\right)$. Cambridge Massachusetts. Phlogiston Press

Nuraini, T. W., Murdaniel, R. P. S., \& Harahap, M. H. (2013). Upaya penanganan mutu ikan tuna segar hasil tangkapan kapal longline untuk tujuan ekspor. Marine Fisheries. 4(2), 152-162.
Rohsenow, W. M., Hartnett, J. P., \& Cho, Y. I. (Eds). (1998). Handbooks of heat transfer ( $3^{\text {rd }}$ ed). McGraw-Hill

Suryaningrum, T. W., Ikasari, D., \& Octaviani, H. (2017). Evaluasi mutu tuna loin segar untuk sashimi yang diolah di atas perahu selama penanganan dan distribusinya di Ambon. Jurnal Pascapanen dan Bioteknologi Kelautan dan Perikanan. 12(2), 163178

Thirumarimurugan, M., Kannadasan, G. T., \& Ramasamy, E. (2008). Performnace analysis of shell and tube heat exchanger using miscible system. American Journal of Applied Sciences. 5(5), 548-552.

Wibowo, S., Utomo B. S. B. , Suherman, M., \& Putro, S. (2007). Penanganan ikan tuna segar untuk ekspor ke uni eropa. Buku Panduan. Balai Besar Riset Pengolahan Produk dan Bioteknologi Kelautan dan Perikanan.Badan Riset Kelautan dan Perikanan. DKP Jakarta 2007.

Widianto, T. N., Fauzi, A., \& Hakim, A. R. (2016). Rancangan mini cold storage pada kapal menggunakan pendingin kompresi uap. Prosiding Seminar Nasional Hasil Litbang Pengolahan Produk dan Bioteknologi Kelautan dan Perikanan.Pusat Penelitian dan Pengembangan Daya Saing Produk dan Bioteknologi Kelautan dan Perikanan. 241-252.

Widianto, T. N., \& Sedayu, B. B. (2015).Disain sespan berpendingin untuk pedagang ikan keliling. Jurnal Pascapanen dan Bioteknologi Kelautan dan Perikanan. 10(1), 71-82.

Widianto, T.N., Hermawan, W., \& Utomo, B.S.B. (2014). Uji coba peti ikan segar berpendingin untuk pedagang ikan keliling. Jurnal Pascapanen dan Bioteknologi Kelautan dan Perikanan. 9(2), 185-191. 